\title{
Analisis Penyalahgunaan Data Pribadi Dalam Aplikasi Fintech Ilegal Dengan Metode Hibrid
}

\author{
Hendro Wijayanto ${ }^{1)}$, Dedy Hariyadi ${ }^{2}$, Abdul Haris Muhammad ${ }^{3)}$ \\ 1) Program Studi Teknik Informatika, STMIK Sinar Nusantara \\ 2) Program Studi Teknologi Informasi, Universitas Jendral Achmad Yani Yogyakarta \\ 3) Program Studi Teknik Informatika, Fakultas Teknik, Universitas Muhammadiyah Maluku Utara \\ 1) hendro@sinus.ac.id, ${ }^{2)}$ dedy@unjaya.ac.id, ${ }^{3)}$ abdulharis@ummu.ac.id
}

\begin{abstract}
Penetration of internet usage in Indonesia has increased by 10.12\% from 2017 to 2018. This has led to very rapid technological growth, such as the growth of online loan services or Financial Technology (Fintech). This condition makes the emergence of illegal fintech services built by certain groups to reap profits. Illegal fintech service providers stand building applications with a lot of personal data requested at registration. Starting from personal data, family, work up to banking are accompanied by photo evidence and contact numbers. Hybrid analysis is needed to see the extent in which the fintech application treats customer data. In this technique, there are static analysis and dynamic analysis. Static analysis is used to see the extent in which the fintech application runs on Smartphone devices with required data and other policies. Dynamic analysis is used to view the activity of tiles and permissions of fintech applications from source code, malware analysis, and permission analysis. Hybrid analysis results show that all fintech applications have a huge potential for misuse of customer's personal data. This is indicated by the existence of a data collection URL that can be accessed by the public, there are malware activities, READ_PHONE_STATE and READ_CONTACS permissions so that fintech application providers freely monitor all contact activities, locations on the customer's Smartphone. The results of the analysis can be used to recommend fintech service users to be careful of fintech applications. Moreover, it can be used as a reference for making illegal fintech detection frameworks.
\end{abstract}

Keywords : Digital Forensic Analysis, Hybrid Analysis, Fintech, Personal Data, Data Breach

\section{PENDAHULUAN}

Negara Indonesia merupakan negara berkembang dengan tingkat perkembangan yang sangat tinggi dibanding dengan negara di Asia Tenggara. Khususnya dibidang teknologi informasi dan internet. Hal ini terasa dari beberapa kebijakan pemerintah yang mendorong masyarakatnya menggunakan teknologi, mulai dari sektor pendidikan, bisnis, transportasi dan lainnya. Bahkan fenomena politik tak lepas dari keterkaitan teknologi informasi. Masyarakat tingkat menengah-bawah pun harus siap dengan perkembangan yang begitu pesat. Semua ini terbukti dari survey Asosiasi Penyelenggara Jasa Internet Indonesia (APJII) tahun 2018 dalam hal penetrasi dan perilaku pengguna internet Indonesia. Dalam laporannya terdapat peningkatan perubahan pengguna internet dari 54,68\% di tahun 2017 menjadi 64,8\% di tahun 2018, seperti Tabel 1

Tabel 1. Penetrasi Pengguna Internet Indonesia (Asosiasi Penyelenggara Jasa Internet Indonesia (APJII), 2018)

\begin{tabular}{|l|c|c|}
\hline \multicolumn{1}{|c|}{ Tahun } & $\mathbf{2 0 1 7}$ & $\mathbf{2 0 1 8}$ \\
\hline Populasi Penduduk (juta) & 262 & 264,16 \\
\hline Pengguna Internet (juta) & 143,26 & 171,17 \\
\hline Persentase (\%) & $54,68 \%$ & $64,8 \%$ \\
\hline
\end{tabular}


Dari penetrasi pengguna internet tersebut, Pulau Jawa berkontribusi sebesar 55,7\% dari total sebaran pengguna internet di seluruh Indonesia. Dari hasil survey yang sama pula, 93,9 \% pengguna internet di Indonesia tehubung dengan Smartphone setiap hari.

Dengan tingginya angka penguna internet ini, banyak bermunculan industri Financial Technology (Fintech) dimana perkembangannya sudah dimulai dari tahun 2015. Hadirnya Asosiasi Fintech Indonesia (AFI) bertujuan menyediakan partner bisnis dan dapat terbentuknya Bank Indonesia Fintech Office di tahun 2016. Selain itu juga dapat menjadi wadah regulasi fintech yang dapat diawasi oleh Otoritas Jasa Keuangan Indonesia (OJK). Otoritas Jasa Keuangan sendiri sudah mengeluarkan peraturan Nomor 77/POJK.01/2016 tentang Layanan Pinjam Meminjam Uang Berbasis Teknologi Informasi, yang didalamnya berisi penyelenggara, kegiatan usaha, batas pinjaman, sampai dengan mitigasi resiko. Inilah yang menjadi pesatnya industri fintech di Indonesia.

Seiringnya waktu, industri fintech di Indonesia mulai menjamur dengan minimnya pengawasan yang ketat. Otoritas Jasa Keuangan sendiri merilis terdapat sebanyak 404 fintech ilegal di Desember 2018, dimana dibulan November 2018 terdapat 1130 pengaduan korban fintech ilegal. Dengan jenis pelanggaran mulai dari denda keterlambatan yang tinggi, komisi/bunga tinggi dan teror yang dilakukan oleh perusahaan fintech. Di internet sudah banyak aplikasi-aplikasi fintech bersebaran bebas. Bahkan di aplikasi Playstore Android banyak ditemukan aplikasi fintech. Minimnya kesadaran masyarakat terhadap rentannya penyalahgunaan data pribadi, menjadi alasan mudahnya melakukan pengajuan pinjaman atau pembiayaan online lewat aplikasi fintech. Aplikasi fintech yang banyak bertebaran inilah dapat menimbulkan potensi resiko penyalahgunaan data pribadi yang diupload pada saat pengajuan pembiayaan. Apalagi proses pembuatan dan pengembangan aplikasi sangat mudah dilakukan tanpa harus memiliki pengalaman programming. Dari kejadian inilah muncul permasalahan yang menjadi topik besar penelitian ini. Yaitu bagaimana pola aplikasi fintech dalam menyebarkan informasi/data pribadi nasabah ke pihak ketiga sehingga dapat memicu kejahatan dunia maya. Hasil dari analisis ini nantinya dapat digunakan untuk pembuatan framework security assessment dalam hal keamanan data pribadi di aplikasi fintech. Selain dari hal tersebut, dapat digunakan untuk acuan dalam mengenali ciri-ciri fintech illegal yang dapat merugikan masyarakat.

\section{TINJAUAN PUSTAKA}

Seseorang yang dapat diidentifikasi adalah seseorang yang dapat dikenali secara langsung maupun tidak langsung berdasarkan nomor tanda pengenal atau berdasarkan faktor spesifik dari identifikasi fisik, psikologi, mental, budaya atau sosial. Perlindungan data pribadi dalam bidang perbankan telah diatur dalam Pasal 40 Undang-undang Nomor 10 Tahun 1998 tentang perbankan. Berdasarkan ketentuan tersebut bank wajib merahasiakan keterangan mengenai nasabah (Dewi Rosadi \& Gumelar Pratama, 2018).

Data-data pribadi berkenaan dengan kependudukan dan demografis di Indonesia seperti NIK, E-KTP dan KK sangat penting dilindungi agar tidak mudah dieksploitasi. Ada beberapa bentuk penyalahgunaan data seperti penjualan data, data profiling, tujuan pemasaran, penelitian, bahkan termasuk pemantauan/spionase. Yang lebih berbahaya penyalahgunaan data pribadi untuk tindak kriminal seperti pembuatan akun palsu, penipuan, pencucian uang, pemerasan dan transaksi ilegal (Sautunnida, 2018). 
Berdasarkan sumber dari Otoritas Jasa Keuangan (OJK) Indonesia, bahwa fintech ilegal memiliki ciri-ciri sebagai berikut :

1. Tidak memiliki izin resmi

2. Tidak ada identitas pengurus dan alamat

3. Pemberian pinjaman sangat mudah

4. Informasi bunga biaya pinjam dan denda tidak jelas

5. Bunga /biaya pinjam tidak terbatas

6. Total pengembalian (termasuk denda) tidak terbatas

7. Penagihan tidak ada batas waktu

8. Tidak ada layanan pengaduan

9. Akses ke seluruh data yang ada di ponsel

10. Ancaman teror kekerasan, penghinaan, pencemaran nama baik, menyebarkan foto/video pribadi, dan menyebarkan identitas pribadi

Penggunaan data pribadi yang dikelola untuk maksud tertentu tidak boleh tanpa persetujuan subjek data, digunakan untuk maksud lain selain daripada maksud untuk mana data pribadi terebut digunakan. Data pribadi tidak boleh diperlakukan atau digunakan secara bertentangan dengan maksud penggunaannya. Semua langkah akses data yang diperlukan, perlu ditempuh oleh pengelola data untuk mencegah akses data, pemrosesan data, perubahan data, pengungkapan data serta perusakan data yang dapat merugikan nasabah (Rosadi, 2017).

Software reengineering adalah pemeriksaan dan perubahan terhadap sebuah subyek sistem untuk menyusun kembali ke dalam sebuah bentuk yang baru sesuai bentuk yang baru tersebut. Proses rekayasa ulang ini mencakup 4 (empat) tujuan, yaitu Understanding (predictive), Repairing (corrective), Improving (perfective) dan Evolving (adaptive). Sedangkan Reengineering terdiri dari dua proses utama, yaitu reverse dan forward engineering. Reverse engineering merupakan proses yang tidak melibatkan perubahan sistem. Sebuah sistem software dianalisis untuk mengekstrak informasi dari software, maka pilihan yang harus dilakukan adalah antara analisis statis dan dinamik (Rahmadani, Raharjana, \& Taufik, 2015).

Analisis statis merupakan teknik pengumpulan data secara manual. Dimana setiap sistem atau aplikasi dibuka sumber source code-nya dan karakteristik string-nya. Biasanya teknik analisis statis ini hanya melibatkan sedikit tools dan menghasilkan data analisis yang sedikit. Oleh karena itu untuk memperbanyak data yang dibutuhkan, diperlukan metodologi lain, yaitu analisis dinamis. Analisis dinamis melibatkan aplikasi atau sering disebut dengan proses reengineering. Analisis ini memungkinkan sistem/aplikasi dijalankan seperti keadaan sesungguhnya dan dapat dianalisa pola, data serta teknik yang digunakan (Lin, Chen, Zhu, Yang, \& Wei, 2018).

Dalam sebuah aplikasi terdapat kategori dimana aplikasi tersebut dikatakan aman dari penyalahgunaan data (Mark, 2013), yaitu :

1. Kontrol akses aplikasi yang memastikan identitas di autentikasi dan di otorisasi untuk melihat data yang dilindungi melalui aplikasi.

2. Aplikasi harus memastikan keamanan koneksi antara pengguna, database dan aplikasi.

3. Audit dan pencatatan aktifitas untuk memberikan pelaporan yang valid dan tidak valid setiap aktifitas dalam aplikasi.

4. Kode aplikasi dan manajemen konfigurasi yang memastikan kode tersebut aman. 
Kategori inilah yang menjadi ukuran data pengguna aplikasi dijamin keamanannya dari penyalahgunaan pihak luar maupun dalam sistem aplikasi.

Digital forensik merupakan metode ilmiah yang digunakan untuk pengumpulan data informasi, identifikasi analisis, interpretasi dan penyajian bukti digital yang berasal dari sumber digital, dengan tujuan memfasilitasi pelaporan atau mengantisipasi tindakan kejahatan dunia maya (Palmer, 2001).

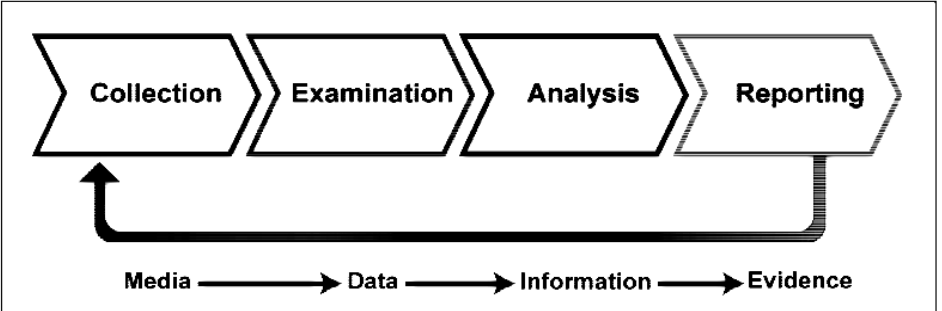

Gambar 1. Digital Forensic Process (Baryamureeba \& Tushabe, 2004)

Dalam digital forensik, terdapat 4 (empat) langkah untuk menemukan bukti digital atau kesimpulan dari suatu kejahatan dunia maya.

1. Collection. Yaitu proses pencarian barang bukti berupa temuan-temuan, pengakuan barang bukti dan dokumentasi.

2. Examination. Pada proses ini data akan ditarik keterkaitannya dengan data lain, kesesuaian, kejelasan dan relevansinya.

3. Analysis. Melakukan pemeriksaan data yang sesuai, membandingkan, menemukan dan menghasilkan fakta-fakta.

4. Reporting. Penulisan laporan uraian dari hasil pemeriksaan dan analisis dari seluruh penyelidikan.

\section{METODE PENELITIAN}

Metode yang digunakan untuk menganalisis aplikasi fintech adalah menggunakan teknik hibrid. Dimana teknik ini tidak lepas dari teknik dasar Digital Forensik dalam melakukan analisis seperti ditunjukkan pada Gambar 1. Alur dari metode penelitian ditunjukkan pada Gmbar 2.

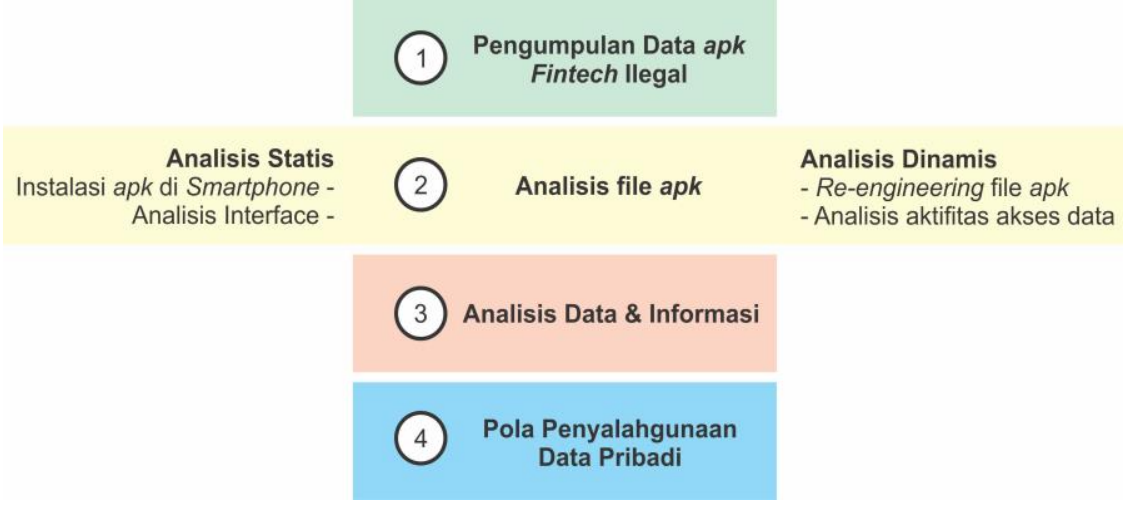

Gambar 2. Metode Analisis Hibrid File apk fintech illegal

File yang dianalisis adalah file dengan ekstensi apk atau paket Android Package File. Dimana file apk merupakan file berkas yang digunakan oleh Smartphone android sebelum dilakukan instalasi. Adapun tahapan analisis hibrid yaitu : 
Tahap 1 Pengumpulan data apk fintech ilegal. Pengambilan data aplikasi dilakukan dengan cara mendownload langsung file apk fintech ilegal yang dirilis oleh Otoritas Jasa Keuangan (OJK) Indonesia. Dalam penelitian ini digunakan 5 sampel data aplikasi fintech berekstensi apk.

Tahap 2 Analisis file apk. Dalam proses analisis dilakukan menggunakan model hibrid. Dimana didalamnya terdapat analisis statis dan analisis dinamis. Pada tahapan analisis statis, aplikasi apk dicoba di install langsung di dalam Smartphone kemudian dilakukan analisis interface dan data yang dimasukkan. Sedangkan analisis dinamis dilakukan dengan cara melakukan re-engineering source code dan analisis keamanan proses berjalannya aplikasi fintech serta aktifitas malware. Proses re-engineering dapat ditunjukkan pada Gambar 3

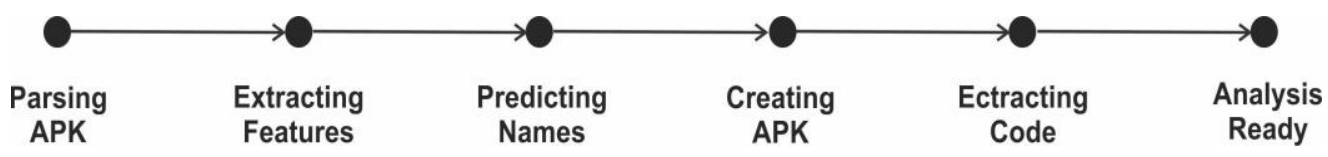

Gambar 3. Proses Re-Engineering File apk

Tahap 3 Analisis data dan informasi. Tahapan ini dilakukan setelah file apk ditemukan data-data dan informasi terkait penyalahgunaan data nasabah/pengguna aplikasi fintech. Data dan informasi ini akan menggambarkan karakteristik masing-masing aplikasi fintech dalam proses mengambil data pribadi pengguna. Mulai dari data KTP, data kerabat/keluarga, data kontak yang berada di smartphone, data perbankan, model penyebaran data pribadi di internet, sampai dengan data dan informasi perilaku aplikasi dalam Smartphone.

Tahap 4 Pola penyalahgunaan data pribadi. Setelah ditemukan ciri dan model aplikasi fintech dalam mencuri dan menyebarluaskan data pribadi nasabahnya, akan dikelompokkan dan dapat ditarik kesimpulan berupa pola penyalahgunaan data pribadi nasabah fintech.

\section{HASIL DAN PEMBAHASAN}

Dalam penelitian ini, digunakan lima data sampel aplikasi fintech ilegal berbasis Android yang didapat dari rilis resmi Otoritas Jasa Keuangan (OJK) dan di unduh dari URL Web maupun Play Store Google. Beberapa aplikasi memang sudah tidak ada atau dihapus dari Play Store atas otoritas keamanan Indonesia untuk meminimalisir terjadinya korban penyalahgunaan data pribadi. Tetapi aplikasi masih dapat diperoleh lewat URL web fintech ilegal tersebut atau lewat apk bucket dan apk pure.

\subsection{Analis Statis Aplikasi Fintech Ilegal Android apk}

Analisis statis diawali dengan meng-install aplikasi kedalam Smartphone Android. Dalam penelitian ini tidak menggunakan emulator karena dimungkinkan hasil analisis kurang akurat. Disebabkan di dalam emulator tidak terdapat nomor telepon dan pencatatan lokasi sebagai syarat utama verifikasi masuk ke aplikasi. Analisis interface diperlukan untuk melihat sejauh mana aplikasi meminta data nasabah dalam proses pengajuan pinjaman online. Adapun hasil dari analisis statis ditunjukkan pada Tabel 2 berikut 
Tabel 2. Hasil Analisis Statis Aplikasi Fintech Ilegal

\begin{tabular}{|c|c|c|c|c|c|}
\hline Data / Informasi & (1) Uang Now & (2) Duit Kita & (3) Dompet Kredit & (4) Raja Uang & (5) Mitra Dana \\
\hline Developer & Hemm Picken & Denise Scioneaux & Colman Scot & NA & $\begin{array}{l}\text { KSP Mitra Dana } \\
\text { Nusantara }\end{array}$ \\
\hline URL Web & $\begin{array}{c}\text { http://uangnow.co } \\
\mathrm{m} /\end{array}$ & NA & NA & $\begin{array}{l}\text { http://www.rajau } \\
\text { ang.mobi/ }\end{array}$ & $\begin{array}{l}\text { http://www.mitrada } \\
\text { na nusantara.com }\end{array}$ \\
\hline Nama File & $\begin{array}{c}\text { com.bbdd.cabjagb } \\
\text { bagcfef_2019- } \\
\text { 06-11.apk }\end{array}$ & $\begin{array}{l}\text { DuitKita kredit lancar } \\
\text { hidup lancar } \\
\text { Cepat_v1.0.11. } \\
42418 \text { apkpure.com }\end{array}$ & $\begin{array}{c}\text { com.beomargin. } \\
\text { DompetKredit } \\
\text { 2018-09-28 }\end{array}$ & $\begin{array}{l}\text { mobi.uangraja. } \\
\text { android_2018- } \\
09-19\end{array}$ & $\begin{array}{c}\text { anda.mcvbmxb.jsd } \\
\text { gh_2019-06-15 }\end{array}$ \\
\hline $\begin{array}{l}\text { Kebijakan } \\
\text { Privasi dan } \\
\text { Penggunaan } \\
\text { Data } \\
\end{array}$ & Ada & Ada & $\begin{array}{c}\text { Tidak Jelas / Tidak } \\
\text { Ada }\end{array}$ & $\begin{array}{l}\text { Tidak Jelas / } \\
\text { Tidak Ada }\end{array}$ & $\begin{array}{c}\text { Tidak Jelas / Tidak } \\
\text { Ada }\end{array}$ \\
\hline $\begin{array}{l}\text { Informasi } \\
\text { Pinjaman \& } \\
\text { Bunga }\end{array}$ & $\begin{array}{l}\text { 1. Jumlah } \\
\text { Pinjaman Rp. } \\
\text { 1.000.000,- s.d } \\
\text { Rp. } 2.000 .000,- \\
\text { 2. Bunga Tidak } \\
\text { Dijelaskan } \\
\text { 3. Jangka Waktu } 7 \\
\text { hari untuk } \\
\text { semua plaform }\end{array}$ & $\begin{array}{l}\text { 1. Jumlah Pinjaman } \\
\text { Rp. 1.000.000,- s.d } \\
\text { Rp. 15.000.000,- } \\
\text { 2. Bunga Tidak } \\
\text { Dijelaskan } \\
\text { 3. Jangka Waktu tidak } \\
\text { dijelaskan }\end{array}$ & $\begin{array}{l}\text { 1.Jumlah } \\
\text { Pinjaman Rp. } \\
\text { 1.000.000,- s.d } \\
\text { Rp. } \\
\text { 10.000.000,- } \\
\text { 2. Bunga Tidak } \\
\text { Dijelaskan } \\
\text { 3.Jangka Waktu } 7 \\
\text { - } 14 \text { hari }\end{array}$ & $\begin{array}{ll}\text { 1. Jumlah } \\
\text { Pinjaman Rp. } \\
600.000,- \text { s.d } \\
\text { Rp. } \\
\text { 2.000.000,- } \\
\text { 2. } \text { Bunga Tidak } \\
\text { Dijelaskan } \\
\text { 3. Jangka Waktu } \\
7 \text { - } 14 \text { hari }\end{array}$ & $\begin{array}{l}\text { 1. Jumlah } \\
\text { Pinjaman Rp. } \\
1.000 .000,- \\
\text { 2. Bunga 0.07\% } \\
\text { 3. Jangka Waktu } \\
14 \text { hari }\end{array}$ \\
\hline Data Pribadi & $\begin{array}{ll}\text { 1. } & \text { NIK } \\
\text { 2. } & \text { Nama } \\
\text { lengkap } \\
\text { 3. } \text { Tempat \& } \\
\text { tanggal lahir } \\
\text { 4. Alamat } \\
\text { lengkap } \\
\text { 5. Jenis kelamin } \\
\text { 6. Agama } \\
\text { 7. Status } \\
\text { 8. Hunian/Ruma } \\
\text { h }\end{array}$ & $\begin{array}{l}\text { 1.NIK } \\
\text { 2. Nama lengkap } \\
\text { 3. Tempat \& tanggal } \\
\text { lahir } \\
\text { 4. Alamat lengkap } \\
\text { 5. Jenis kelamin } \\
\text { 6. Agama } \\
\text { 7.Status } \\
\text { 8. Hunian/Rumah } \\
\text { 9.NPWP }\end{array}$ & $\begin{array}{l}\text { 1.NIK } \\
\text { 2. Nama lengkap } \\
\text { 3. Tempat \& } \\
\quad \text { tanggal lahir } \\
\text { 4.Alamat lengkap } \\
\text { 5.Jenis kelamin } \\
\text { 6. Agama } \\
\text { 7.Status }\end{array}$ & $\begin{array}{l}\text { 1. NIK } \\
\text { 2. Nama } \\
\text { lengkap } \\
\text { 3. Tempat \& } \\
\text { tanggal lahir } \\
\text { 4. Alamat } \\
\text { lengkap } \\
\text { 5. Jenis kelamin } \\
\text { 6. Agama } \\
\text { 7. Status }\end{array}$ & $\begin{array}{l}\text { 1. NIK } \\
\text { 2. Nama lengkap } \\
\text { 3. Tempat \& } \\
\quad \text { tanggal lahir } \\
\text { 4. Alamat lengkap } \\
\text { 5. Jenis kelamin } \\
\text { 6. Agama } \\
\text { 7. Status }\end{array}$ \\
\hline Data Keluarga & $\begin{array}{l}\text { 1.Ibu Kandung } \\
\text { 2.Saudara } \\
\text { Sekandung } \\
\text { 3.Jumlah Anak }\end{array}$ & $\begin{array}{ll}\text { 1. } & \text { Ibu Kandung } \\
\text { 2. } & \text { Saudara } \\
\text { Sekandung } \\
\text { 3. Jumlah Anak }\end{array}$ & 1. $\mathrm{lbu} \mathrm{Ka}$ & $\begin{array}{l}\text { 1. Ibu Kandung } \\
\text { 2. Saudara } \\
\text { Sekandung }\end{array}$ & $\begin{array}{l}\text { 1. Ibu Kandung } \\
\text { 2. Saudara } \\
\text { Sekandung }\end{array}$ \\
\hline $\begin{array}{l}\text { Data Kontak } \\
\text { Telepon }\end{array}$ & $\begin{array}{l}\text { 1. Ayah Kandung } \\
\text { 2. Ibu Kandung } \\
\text { 3.Kerabat Dekat } \\
\text { Minimal 2 } \\
\end{array}$ & $\begin{array}{l}\text { 1. Ibu Kandung } \\
\text { 2. Kerabat Dekat } \\
\text { Minimal } 3\end{array}$ & $\begin{array}{ll}\text { 1. } & \text { Ibu Kandung } \\
\text { 2. } & \text { Kerabat Dekat } \\
& \text { Minimal } 2\end{array}$ & $\begin{array}{l}\text { 1. Ibu Kandung } \\
\text { 2. Kerabat Dekat } \\
\text { Minimal } 2\end{array}$ & $\begin{array}{l}\text { 1. Ibu Kandung } \\
\text { 2. Kerabat Dekat } \\
\text { Minimal } 3\end{array}$ \\
\hline Data Pekerjaan & $\begin{array}{l}\text { 1.Instansi } \\
\text { 2.Alamat Instansi } \\
\text { 3. Telp Instansi } \\
\text { 4.Posisi } \\
\quad \text { Pekerjaan } \\
\text { 5.Lama Pekerjaan } \\
\text { 6. Gaji }\end{array}$ & $\begin{array}{ll}\text { 1. } & \text { Instansi } \\
\text { 2. Alamat Instansi } \\
\text { 3. Telp Instansi } \\
\text { 4. Posisi Pekerjaan } \\
\text { 5. Lama Pekerjaan } \\
\text { 6. Gaji }\end{array}$ & $\begin{array}{l}\text { 1. Instansi } \\
\text { 2. Alamat Instansi } \\
\text { 3. Telp Instansi } \\
\text { 4. Posisi } \\
\text { Pekerjaan } \\
\text { 5. Lama Pekerjaan } \\
\text { 6. Gaji }\end{array}$ & $\begin{array}{ll}\text { 1. Instansi } \\
\text { 2. } \text { Alamat } \\
\text { Instansi } \\
\text { 3. Telp Instansi } \\
\text { 4. Posisi } \\
\text { Pekerjaan } \\
\text { 5. Lama } \\
\text { Pekerjaan } \\
\text { 6. Gaji } \\
\end{array}$ & $\begin{array}{l}\text { 1. Instansi } \\
\text { 2. Alamat Instansi } \\
\text { 3. Telp Instansi } \\
\text { 4. Posisi } \\
\text { Pekerjaan } \\
\text { 5. Lama Pekerjaan } \\
\text { 6. Gaji }\end{array}$ \\
\hline $\begin{array}{l}\text { Data Perbankan } \\
\text { dan Lainnya }\end{array}$ & Tidak Ada & $\begin{array}{l}\text { 1. Rekening Tabunga } \\
\text { Bank Lain } \\
\text { 2. Kartu Kredit }\end{array}$ & Tidak Ada & Tidak Ada & $\begin{array}{c}\text { Rekening } \\
\text { Tabungan Bank } \\
\text { Lain }\end{array}$ \\
\hline Data File Upload & $\begin{array}{ll}\text { 1. } & \text { Foto Pribadi \& } \\
\text { KTP }\end{array}$ & $\begin{array}{l}\text { 1. Foto Pribadi \& KTP } \\
\text { 2. Foto NPWP } \\
\text { 3. Foto Whatsapp }\end{array}$ & $\begin{array}{l}\text { 1. Foto Pribadi \& } \\
\text { KTP }\end{array}$ & $\begin{array}{ll}\text { 1. } & \text { Foto Pribadi } \\
& \& \text { KTP }\end{array}$ & $\begin{array}{ll}\text { 1. Foto Pribadi \& } \\
\text { KTP }\end{array}$ \\
\hline Data Agunan & Tidak Ada & Tidak Ada & k Ada & Tidak Ada & Tidak Ada \\
\hline $\begin{array}{l}\text { Data Media } \\
\text { Sosial }\end{array}$ & $\begin{array}{l}\text { 1. Whatsapp } \\
\text { 2. Facebook }\end{array}$ & $\begin{array}{ll}\text { 1. } & \text { Whatsapp } \\
\text { 2. Email } \\
\text { 3. Facebook } \\
\text { 3. Instagram } \\
\end{array}$ & Tidak Ada & Tidak Ada & $\begin{array}{l}\text { 1. Facebook } \\
\text { 2. Instagram } \\
\text { 3. Whatsapp }\end{array}$ \\
\hline $\begin{array}{l}\text { Verifikasi SMS/ } \\
\text { Telp }\end{array}$ & SMS & SMS & SMS & SMS dan Telp & SMS \\
\hline Verifikasi Lokasi & $\mathrm{G}$ & GPS & PS & GPS & SS \\
\hline $\begin{array}{l}\text { Verifikasi Video } \\
\text { Call }\end{array}$ & Tidak Ada & Tidak Ada & Tidak Ada & Tidak Ada & Tidak Ada \\
\hline $\begin{array}{l}\text { Model Pencairan } \\
\text { \& Pengembalian }\end{array}$ & Transfer Bank & Transfer Bank & Transfer Bank & Transfer Bank & Transfer Bank \\
\hline
\end{tabular}


Dari hasil analisis statis Tabel 2 diatas dapat ditarik kesimpulan bahwa terdapat data penting dan proses penting yang seharusnya melalui verifikasi dan dokumentasi. Kebijakan privasi dan penggunaan data merupakan ukuran pertama yang harus disiapkan oleh penyedia layanan pinjaman online. Kebijakan ini merupakan sebuah perjanjian awal dalam penggunaan dan transaksi data informasi yang diberikan oleh calon peminjam. Dari kelima sampel diatas, hanya 2 yang memberikan informasi kebijakan privasi data. Akan tetapi hal ini tidak menjadi ukuran pasti bahwa penyedia layanan akan menjaga dengan benar data pribadi tersebut. Kebijakan tersebut akan berpengaruh terhadap kerahasiaan data pribadi, data keluarga, data kontak, data pekerjaan, data perbankan dan data media sosial. Selain itu layanan verifikasi video call juga tidak disediakan di aplikasi pinjaman online. Verifikasi video call merupakan cara penyedia layanan untuk memastikan bahwa calon peminjam yakin dengan layanan yang diberikan. Selain itu, penggunaan verifikasi video call ini akan meminimalisir penggunaan data calon peminjam online.

\subsection{Analis Dinamis Aplikasi Fintech Ilegal Android apk}

Analisis dinamis dilakukan menggunakan 2 (dua) cara. Pertama yaitu menggunakan teknik re-engineering file apk, yang nantinya merubah file apk menjadi file source code untuk dapat dianalisis alur sistemnya. Sedangkan yang kedua menggunakan teknik analisis proses genetik, atau sering disebut Genetik Malware Analysis. Teknik ini akan melihat proses apk apakah mengandung aktifitas mencurigakan dalam pencurian data informasi atau tidak.

\subsubsection{Re-enginering File apk}

Tahapan proses re-engineering dari file apk menjadi source code dapat dilihat pada Gambar 3. Re-engineering atau Deobfuscation dalam penelitian ini menggunakan tools apk-deguard
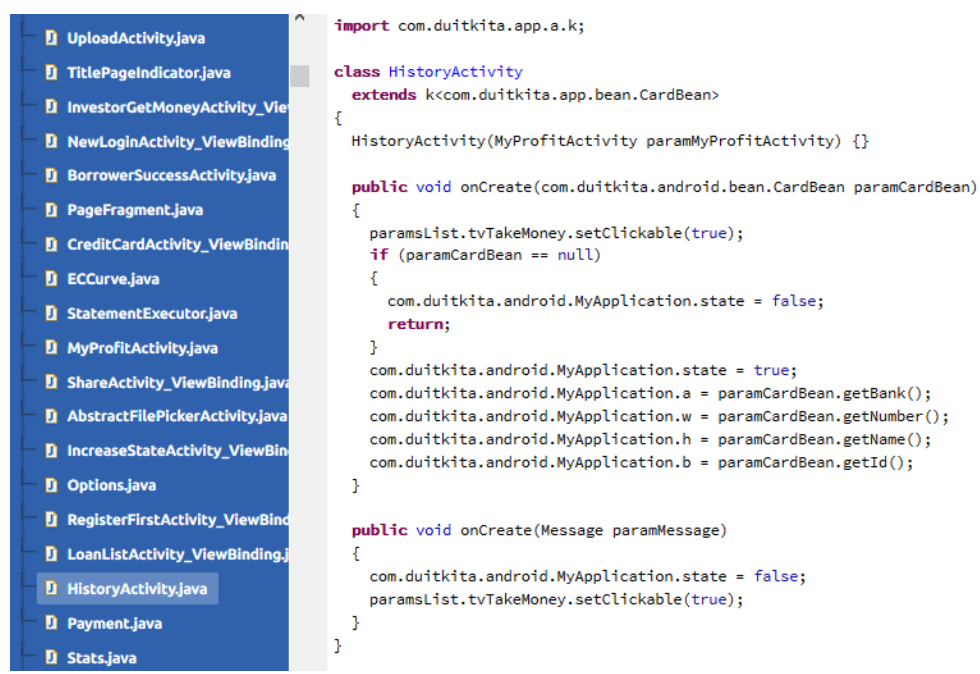

Gambar 4. Deobfuscation file apk fintech ilegal

Proses deobfuscation menunjukkan bahwa sampel aplikasi menunjukkan alamat $U R L$ admin mereka dan bahkan melakukan verifikasi data perbankan seperti data Kartu Kredit. Karena beberapa alamat URL sampel aplikasi ini sudah diblokir, dibutuhkan akses proxy untuk dapat masuk ke dalamnya. Beberapa $U R L$ juga mulai dinonaktifkan demi keamanan nasabah fintech. 


\subsubsection{Analisis Aktifitas Genetik}

Analisis genetik dilakukan untuk melihat aktifitas yang menyerupai aktifitas backdoor, malware dan virus. Dimana aktifitas tersebut dapat memicu pencurian data. Analisis menggunakan tools Intezer, dan Virustotal. Selain itu juga dapat untuk mengetahui aktifitas apa saja yang dilakukan aplikasi pada saat berjalan.

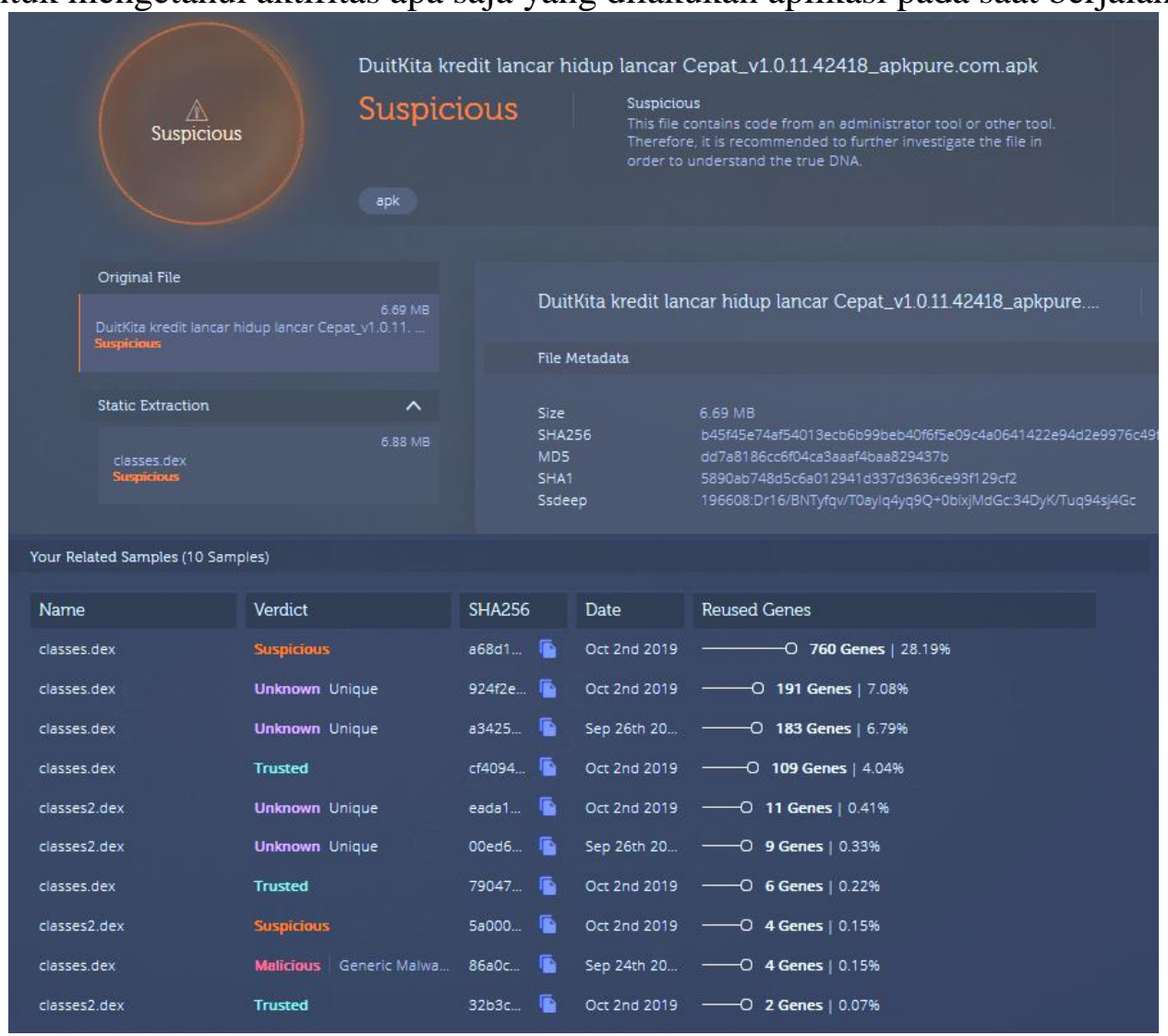

Gambar 5. Analisis Aktifitas Genetik dengan Intezer

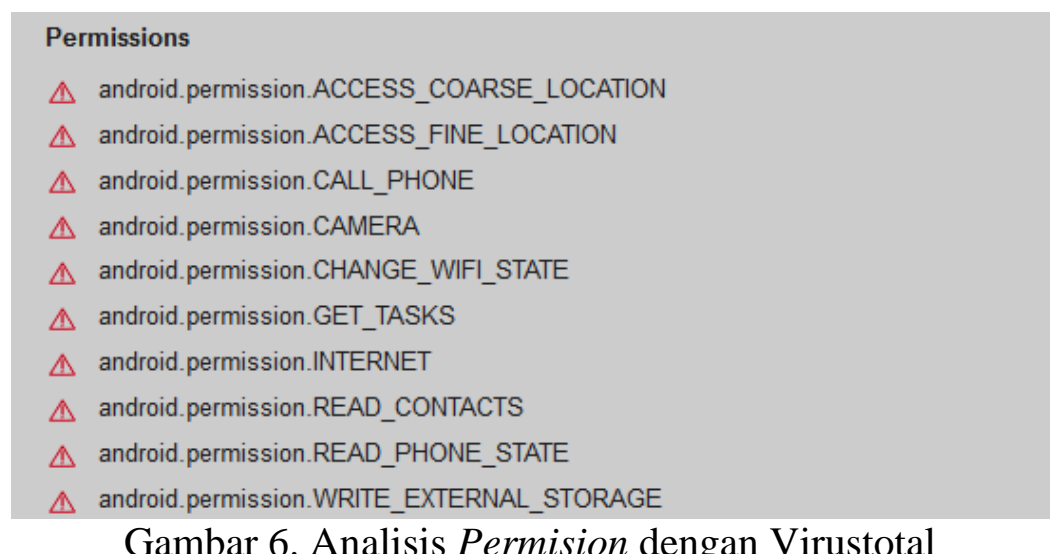

Berdasarkan analisis Gambar 5 dan Gambar 6, bahwa ternyata aplikasi fintech ilegal ini mengandung aktifitas malware yang sengaja diciptakan oleh Administrator fintech untuk dapat mengambil data lebih banyak dari nasabah fintech. Aktifitas ini dapat dikatakan ilegal karena vendor aplikasi dapat membuka informasi/berkas utuh dari data personal nasabah. Kesimpulan hasil analisis dinamis dapat ditunjukkan pada Tabel 3. Dalam Tabel 3 dapat ditunjukkan 
perbandingan antar aplikasi fintech dalam hal sejauh mana aplikasi tersebut mampu mengambil data / informasi pengguna fintech.

Tabel 3. Hasil Analisis Dinamis Aplikasi Fintech Ilegal

\begin{tabular}{|c|c|c|c|c|c|}
\hline $\begin{array}{c}\text { Data / } \\
\text { Informasi }\end{array}$ & (1) Uang Now & (2) Duit Kita & $\begin{array}{l}\text { (3) Dompet } \\
\text { Kredit }\end{array}$ & (4) Raja Uang & (5) Mitra Dana \\
\hline $\begin{array}{l}\text { Akses Data } \\
\text { (apk- } \\
\text { deguard) }\end{array}$ & Terbuka & Terbuka & Terbuka & Terbuka & Terbuka \\
\hline $\begin{array}{l}\text { Aktifitas } \\
\text { Malware } \\
\text { (Intezer) }\end{array}$ & Mencurigakan & Mencurigakan & Terpercaya & Mencurigakan & Mencurigakan \\
\hline $\begin{array}{l}\text { Permissions } \\
\text { (Virus Total) }\end{array}$ & $\begin{array}{l}\text { 1. ACCESS_C } \\
\text { OARSE_LO } \\
\text { CATION } \\
\text { 2. ACCESS_F } \\
\text { INE_LOCA } \\
\text { TION } \\
\text { 3. CAMERA } \\
\text { 4. INTERNET } \\
\text { 5. READ_CO } \\
\text { NTACTS } \\
\text { 6. READ_PH } \\
\text { ONE_STAT } \\
\text { E } \\
\text { 7. WRITE_EX } \\
\text { TERNAL_S } \\
\text { TORAGE }\end{array}$ & $\begin{array}{l}\text { 1. } \text { ACCESS } \\
\text { COARSE- } \\
\text { LOCATIO } \\
\text { LOC } \\
\text { 2. ACCESS } \\
\text { FINE_LOC } \\
\text { ATION } \\
\text { 3. CALL_PH } \\
\text { ONE_PH } \\
\text { 4. CAMERA } \\
\text { 5. CHANGE_- } \\
\text { WIFI_STA } \\
\text { TE } \\
\text { 6. GET_TAS } \\
\text { KS - } \\
\text { 7. NTERNET } \\
\text { 8. READ_CO } \\
\text { NTACTS } \\
\text { 9. READ_PH } \\
\text { ONE_STA } \\
\text { TE } \\
\text { 10. WRITEE } \\
\text { XTERNAL } \\
\text { STORAG } \\
\text { E }\end{array}$ & $\begin{array}{l}\text { 1. CAMERA } \\
\text { 2. GET_TASKS } \\
\text { 3. INTERNET } \\
\text { 4. READ_PHON } \\
\text { E_STATE } \\
\text { 5. WRITE_EXTE } \\
\text { RNAL_STOR } \\
\text { AGE }\end{array}$ & $\begin{array}{l}\text { 1. ACCESS_CO } \\
\text { ARSE_LOCA } \\
\text { TION } \\
\text { 2. ACCESS_FIN } \\
\text { E_LOCATION } \\
\text { 3. CAMERA } \\
\text { 4. GET_TASKS } \\
\text { 5. INTERNET } \\
\text { 6. READ_CALL } \\
\text { LOG_ } \\
\text { 2. READ_CONT } \\
\text { ACTS } \\
\text { 8. READ_PHON } \\
\text { E_STATE } \\
\text { 9. READ_SMS } \\
\text { 10. RECO } \\
\text { RD_AUDIO } \\
\text { 11. WRIT } \\
\text { E_EXTERNA } \\
\text { L_STORAGE }\end{array}$ & $\begin{array}{l}\text { 1.ACCESS_COA } \\
\text { RSE_LOCATIO } \\
\text { N } \\
\text { 2.ACCESS_FINE } \\
\text { _LOCATION } \\
\text { 3. CALL_PHONE } \\
\text { 4.CAMERA } \\
\text { 5.CHANGE_WIFI } \\
\text { STATE } \\
\text { 6.INTERNET } \\
\text { 7.READ_CONTA } \\
\text { CTS } \\
\text { 8. READ_PHONE } \\
\text { STATE } \\
\text { 9. READ_PROFIL } \\
\text { E REACOR } \\
\text { 10. RECOR } \\
\text { D_AUDIO } \\
\text { 11. SYSTE } \\
\text { M_ALERT_WIN } \\
\text { DOW WW WRITE } \\
\text { 12. EXTERNAL_ST } \\
\text { ORAGE }\end{array}$ \\
\hline
\end{tabular}

Permissions dalam sebuah sistem adalah pemberian izin aplikasi terhadap informasi dan data yang ada di dalam Smartphone. Dari Tabel 3 diketahui bahwa semua aplikasi fintech meminta permission untuk melakukan pembacaan penyimpanan di Smartphone, yaitu permission READ_PHONE_CONTACTS. Selain itu juga terdapat permintaan izin untuk pembacaan daftar kontak telepon yang tersimpan di Smartphone, yaitu READ_CONTACTS. Hal ini dapat disimpulkan bahwa data informasi yang tersimpan dalam Smartphone dapat diakses oleh vendor/administrator fintech, ketika di dalam Smartphone terinstall aplikasi tersebut. Sehingga berpotensi data informasi yang seharusnya tidak dibutuhkan untuk syarat pengajuan pinjaman, dapat diambil oleh vendor fintech ilegal.

\section{KESIMPULAN DAN SARAN}

\subsection{Kesimpulan}

Dari penelitian ini dapat disimpulkan bawha :

1. Aplikasi pinjaman online atau fintech ilegal memberikan kemudahan dalam bertransaksi dengan banyak data pribadi yang diperlukan untuk pendaftaran. Selain itu meniadakan Video Call sebagai salah satu persyaratan untuk mengganti verifikasi langsung dengan calon nasabah sesuai yang disyaratkan oleh Otoritas Jasa Keuangan (OJK) membuat aplikasi fintech rentn penyalahgunaan data pribadi. 
2. Mudahnya vendor / administrator fintech mengambil data nasabah selain data yang dimasukkan ketika melakukan registrasi fintech. Hal ini terbukti dari Permission aplikasi Android fintech. Seluruh sampel aplikasi memberikan permission READ_PHONE_STATE dan READ_CONTACS sehingga penyedia aplikasi fintech dengan leluasa memantau seluruh aktifitas contact di Smartphone nasabah.

\subsection{Saran}

Dengan mudahnya penyalahgunaan data pribadi di aplikasi fintech, perlu dibuat framework assessment aplikasi fintech yang dapat digunakan sebelum aplikasi diupload di Play Store atau internet. Perlu juga membangun kesadaran masyarakat terhadap pentingnya perlindungan data pribadi dengan cara melakukan sosialisasi terhadap ciriciri aplikasi fintech ilegal.

\section{DAFTAR PUSTAKA}

Asosiasi Penyelenggara Jasa Internet Indonesia (APJII). (2018). Infografis Penetrasi \& Perilaku Pengguna Internet Indonesia. Indonesia.

Baryamureeba, V., \& Tushabe, F. (2004). The Enhanced Digital Investigation Process Model. Proceedings of the Digital Forensic Research Conference, DFRWS 2004 USA, 1-9.

Dewi Rosadi, S., \& Gumelar Pratama, G. (2018). Urgensi Perlindungandata Privasidalam Era Ekonomi Digital Di Indonesia. Veritas et Justitia, 4(1), 88-110. https://doi.org/10.25123/vej.2916

Lin, X., Chen, T., Zhu, T., Yang, K., \& Wei, F. (2018). Automated forensic analysis of mobile applications on Android devices. Digital Investigation, 26, S59-S66. https://doi.org/10.1016/j.diin.2018.04.012

Mark, R.-O. (2013). Information Security The Complete Reference, Second Edition. 896. Retrieved from www.it-ebooks.info/book/3340

Palmer, G. L. (2001). A Road Map for Digital Forensic Research.

Rahmadani, V. S., Raharjana, I. K., \& Taufik, T. (2015). Penerapan Reverse Engineering Dalam Penentuan Pola Interaksi Sequence Diagram Pada Sampel Aplikasi Android. Journal of Information Systems Engineering and Business Intelligence, 1(1), 25. https://doi.org/10.20473/jisebi.1.1.25-32

Rosadi, S. D. (2017). Prinsip-Prinsip Perlindungan Data Pribadi Nasabah Kartu Kredit Menurut Ketentuan Nasional dan Implementasinya. Sosiohumaniora, 19(3), 206212.

Sautunnida, L. (2018). Urgensi Undang-undang Perlindungan Data Pribadi di Indonesia. Kanun Jurnal Ilmu Hukum, 20(2), 369-384. 